\title{
Determinants of Personal Transformation among Muslim: Initiator, Obstacle, and Supporting Factors
}

\author{
Nita Trimulyaningsih ${ }^{1,2}$, Subandi ${ }^{1}$, Kwartarini Wahyu Yuniarti ${ }^{1}$ \\ 1 Faculty of Psychology, Universitas Gadjah Mada, Yogyakarta, Indonesia; \\ 2 Faculty of Psychology and Social Cultural Science, Universitas Islam Indonesia, Yogyakarta, \\ Indonesia. \\ nitatri@uii.ac.id,subandi@ugm.ac.id,kwartarini_psy@ugm.ac.id
}

\begin{abstract}
Every humans need a continous changes to actualize all of their potential. Personal transformation often used by researchers and experts to refer this biological and psychological changes. This process is not a momentary process, but a dynamic, lifelong, with difficulties and obstacles. Many factors can affect it's process. Several factors have known as determinant of personal transformation generally, but these variables may not appropriately apply in Indonesia which dominantly Muslim. So, there is a need to reveal determinants of personal transformation among muslim in Indonesia. This study aims to explore the determinants of personal transformation among muslim in a character school in Indonesia. The research method is qualitative exploratory research with open ended questionaire, FGD, and interviews. In the results, religiousity, social support, and meaning of life seems dominantly initiate and support the transformation process. Another variables also found as initiative and supporting variables. In this research, seems that obstacle of transformation come from stressor in life, significant others, also internal factors like spiritual sickness in the heart, and dependency. The dynamic of determinants and theoretical explanation discussed. Further process of deepening the findings is needed.
\end{abstract}

Keywords: personal transformation, determinant, initiator, obstacle, and supporting factors.

\section{Introduction}

Every humans need a continous changes, go over 'normality' to actualize all of their potential [1]. Personal transformation often used by researchers and experts to refer this biological and psychological changes. Transformation leads to increased personal capacity throughout the domain of functions such as emotions, intellectual, social, and spiritual [2], [3] both qualitatively and quantitatively [4]. This changes occur throughout the life span which can take place suddenly or gradually.

Growth might be a process that is carried out consciously and proactively strives for oneself to achieve higher levels of ability, skills, and other characteristics that are considered valuable, positive and adaptive by individuals [5]. Growth also might happen as a result of individual's encouragement to negotiate normative or multilevel role transitions. Growth will occur at certain times in life when individuals are faced with the task of life orsocial role [6]. This challenge appear with the development of the age of the individual. 
Growth explained as a natural result of environmental stressors and life difficulties. It is a models of personality development namely increased self-awareness, self-acceptance, and social integration [7]. This form of process can take the form of broader control of one's environment, higher resilience in the face of obstacles and challenges, the results of diverse life experiences, the results of activities explored by individuals [8], increased interpersonal relations and respect for others, transform self-perception in order to increase maturity and resilience, and re-determine the philosophy and priorities of life [9].

Some psychological studies have found that growth can occur in mothers and fathers and grandparents involved in the parenting process [10], in dealing with disease [11], [12], and facing life's transition, especially career and religion [13]. This finding shows that growth can occur in various life context. Another life context might enabling growth are school/university. Sheldon, Kasser, Smith, and Share tried to facilitate growth for their student [14].

In our first study, we found that there were growth among the teachers in an Islamic character school. The teachers report cognitive, affective, behavior, social, and spiritual domains of growth [15]. In this first research, it seems that changes occur within the scope of schools. School facilitate growth and transformation via organizational culture. The teachers report the change occur since and while they are teaching and be a part of school.

Profound changes indepth human personality perceived as impossible, or hard things to do. Maslow said that people often belief that over-normality persons indeed born to be different [16]. Indeed, transformation can be achieved by human courage, as a dynamic and lifelong process, of course with it's difficulties and triumphs [17]. There must be so many factors affect the process.

Several factors have known as the determinant factors of personal transformation. Some of these factors have found as the determinant of growth among mothers, fathers and grandparents which involved in the parenthood [18]. The first factor are perceived stress and cognitive appraisals. Cognitive appraisal is a process by which a person decides whether a particular experience is relevant to individuals well-being. People who perceive stress and threat as challenge report greater growth and transformation [19].

Second, sociodemographic variables. Those are gender, larger life changes, age, education and economic status. Mothers report greater growth than fathers. Mothers' larger life changes also associated with increased powerful sense of personal growth, while younger mothers report greater growth than older. Third, internal resources (psychological variables) like selfesteem and attachment orientation. Avoidance and anxiety attachment orientation relate to less growth and transformation [20].

The last factors are external resources. This factors include social support and spouse's growth. Social support contain of love and care, solidarity, satisfaction of individual needs, including material and or instrumental needs. Spouse's growth reports greater opportunity to share the experience with significant other. Sharing life events and experiences with others is associated with growth and positive adaptation [21].

Another research find that growth is influenced by the existence of personal goals [22].

The process of pursuit toward personal goals provide people with experiences of life satisfaction along the process, which influence perceived general emotion and growth. In another way, moving toward goal also bring positive changes in individual's self-concept, lifecircumstances, and basic attitudes or philosophies in life, which can induce shifts in person's happiness and growth-related judgments [23].

These variables explain determinants of growth generally, but these variables may not appropriately apply to different cultures. In Indonesia, religion is the most important 
foundation in life, with the majority of the people as Muslim. This shows the need for research to discuss the determinants of personal transformation in the Indonesian context, especially for Muslim communities. For this reason, this study attempts to explore the determinant of growth and maturation among Islamic character school in Indonesia which it's culture facilitate transformation. Furthermore, from the description, identification is made about the determinant of transformation: initiating variables, supporting variables, and obstacles.

\section{Method}

This research is an exploratory qualitative study. In this qualitative study, open ended questionnaire were used for data collection. Focus group discussion also used to generate data survey. This research was conducted to teachers at an Islamic character school that applied self-growth culture in the process of education for both teachers and students. The teachers reporting experience of growth in our first study. Subjects in this study amounted to 16 teachers (one man, 15 woman). The inclusion criteria in this study include:

1. Minimum age of 22 years old

2. Belief in Islam as the religion of life

3. Report positive changes in life which is indicated by the answer yes to question 1:

"Do you feel that you are experiencing positive changes in your self and your life?"

This study was conducted by distributing open- ended questionaire sheets to teachers at the selected research locations. The questionnaire start with questions about demographic variables and followed with six question:

1. Do you feel experiencing positive changes in yourself and your life? Yes/No*

2. What do you think triggered/encouraged the change in yourself/your life?

3. What obstacles have you encountered in changing your self/life?

4. How do you overcome these obstacles?

5. What/who do you think helped you overcome these obstacles?

Furthermore, the questionaire was welcome to be taken home for collected in the next day. Subjects who met the criteria of inclusion included in the analysis process, while subjects who did not meet the criteria of inclusion did not included in the data analysis process. Based on the data obtained, researchers generate the data used FGD. The data then compiled and analyzed by NVIVO for Mac 11.4.3 program.

\section{Result}

The results of analysis showed at table 1 .

Table 1. Results of the determinants of personal transformation.

\begin{tabular}{ll}
\hline \multicolumn{1}{c}{ Variabel } & N \\
\hline Age & $29-52$ years old \\
Sex & 1 Men \\
& 15 Women \\
Initiating Variables & religiousity (religious experience, religious, practice) \\
& finding meaning of life
\end{tabular}




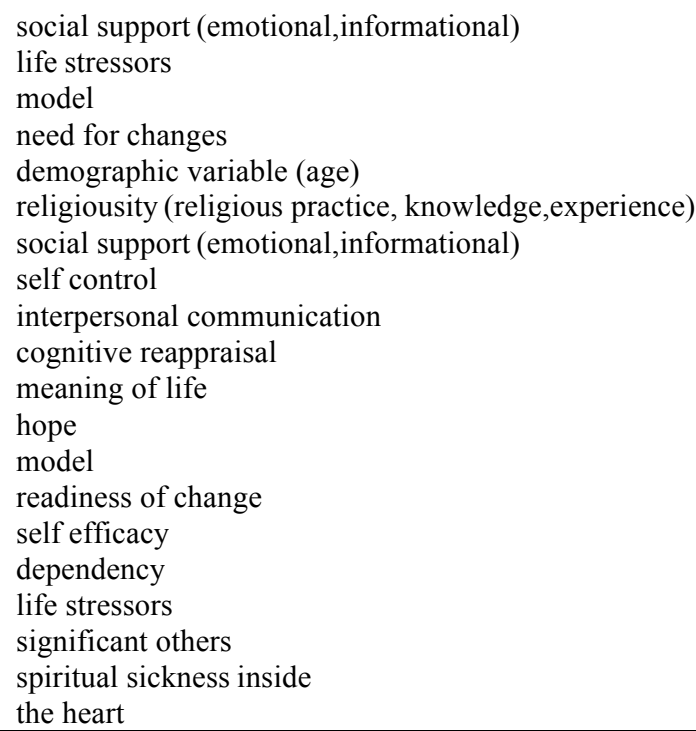

Table one show that religiousity seems to be the major variable initiate the changes, consist of religious knowledge, practice and experience. Some of participants report religious experiences like feeling near with Allah; touched, greeted, guided, reminded by divine reality (God), surrender to God, and also remember about death. This experience initiating and supporting the changes of the self.

How do you overcome these obstacles?

: Return all problems to God, keep the mind open and calm with istighfar, surrender and pray to Allah (Hng)

: Pray, surrender, draw near to God (Ayn)

: Tawakal and istiqomah to Allah (Ilm)

What/who do you think helped you overcome these obstacles

: Tawakal and istiqomah to Allah (Ilm)

$\therefore$ Allah (Hng), (Ayn)

: Allah, the closest people, motivator, myself (Khyr)

: Allah, friend, close friend (Rmn), (Khyr)

In another dimension of religious, participant feel that religious practice (generally) supporting the process of growth, while practicing and teaching istighfar (specifically) promote the changes. Religious practice here refer to activity of praying and $d z i k r$.

How do you overcome these obstacles?

: Return all problems to God, keep the mind open and calm with istighfar, surrender and pray to Allah (Hng)

: More assertive, more dhikr and istighfar (El) 
: Istighfar (done even though it is inconsistent) becomes far more able to control negative thoughts (St)

: Pray, surrender, draw near to Allah (Ayn)

Finding meaning of life also said to be the initiator and supporting variable of changes. Meaning of life here refer to social role as a mother and teacher.

What do you think triggered/encouraged the change in yourselflyour life?

: the desire to change because you want to be a good mother for children (Ek)

: the meaning of meeting with the teacher / person and the problem is a reminder to

God and a medium of self-recognition (Hng)

$\therefore$... remembering death, ..... (Khyr)

It is assumed that this variable is related to another variable found in this research: life stressor and cognitive appraisals. Life stressor in this research find to be an initiating variable and also be the obstacle of growth.

What do you think triggered/encouraged the change in yourselflyour life?

: family problems, parents, more prominent characters, brothers and sisters (Bqs)

: many abstract and unpleasant events (Cnd)

What obstacles have you encountered in changing your self/life?

: Environment and people, life problems, inability to read signs, feeling lonely (Hng)

This research also find that presence of inspiring model as the initiating and supporting model.

: counselor at school, friend, yourself (St)

: learn from friends and students, teachers at school, mentors at school (Rmn)

: meetings with school consultants (El)

Based on the results, it can be seen that social support initiating and supporting the process of growth.

What do you think triggered/encouraged the change in yourselflyour life?

: acceptance of people in school, no judgment (Rsm, Frd)

: care and affection from others (Ilm)

What do you think triggered/encouraged the change in yourselflyour life?

: people, religious books (Frd)

It also can be seen in the results of the analysis that the subjects felt that lack of support from the closest environment was an obstacle in the process of self-growth. 
Along with that, almost all the teachers felt that they were able to surpass the obstacles in the changes that occurred when getting support from the people around

What obstacles have you encountered in changing your selfllife?

:Nearest person (GSM)

:Environment and people, life problems, inability to read signs, feeling lonely (Hng)

:Husband (Ek)

:Husband (st)

:There is a difference with the closest person (Ayn)

:afraid of not getting support (St)

What/who do you think helped you overcome these obstacles?

:Family in school (GSM)

:Teacher (Hng)

:Mother (Ilm)

:Stories / stories of friends in facing life challenges, strong determination to make people happy, children and students in school, Allah (Ek)

:Allah (Hng), (Ayn)

:God, the closest people, motivator, yourself (Khyr)

:Someone who wants to listen and is invited to exchange ideas (Frd)

:Ortu, teacher, sister, children (Bqs)

:People around (Hln)

:Children (st)

:Allah, friend, friend (Rmn)

:Self (El)

: Confidence in self, family, late grandfather, headmaster (Cnd)

In this research, interpersonal communication also found as an supporting variable in the process of growth. In the process, interpersonal communication has an important role to gain social support.

How do you overcome these obstacles? More assertive... (El)

... discuss (Frd)

Providing as much understanding as possible, trying to change oneself and hoping that others will change as self changes, pray (St.)

In initiating the process of transformation, participant perceive that age will lead to naturally personal growth.

What do you think triggered/encouraged the change in yourselflyour life?

increasing age, strong desire to change, remembering death, guidance (Khyr) maturity and increasing age, learning (Hln)

In addition, there are several internal factors that are assumed to initiate and support transformation process. For initiating variable, there is individual's need for changes.

What do you think triggered/encouraged the change in yourself/your life?

the desire to change because you want to be a good mother for children (Ek) 
increasing age, strong desire to change, remembering death, guidance (Khyr)

For supporting variables, there are self control, readiness of change, and self efficacy. Inside the self control, participants report learn to control their cognition, emotion, and behavior.

What obstacles have you encountered in changing your self/life?

:Not able to be consistent (Khyr)

How do you overcome these obstacles?

:Trying to concern yourself with other things that can make it survive the desired changes (Rsm)

:Return all problems to God, keep the mind open and calm with istighfar, surrender and pray to Allah (Hng)

:Istighfar (done even though it is inconsistent) becomes far more able to control negative thoughts (St)

: Remind yourself to stay calm (Rom)

: Shut up, calm down, think, discuss (Frd)

: Providing as much understanding as possible, trying to change oneself and hoping that others will change as self changes, pray (St.)

In addition, there are several internal factors that are assumed to initiate and support transformation process. For initiating variable, there is individual's need for changes.

What do you think triggered/encouraged the change in yourself/your life?

the desire to change because you want to be a good mother for children (Ek)

\section{Discussion}

In this research, it can be seen that this transformation was not so simple, but a dynamic process, along with person's lifespan, with obstacles inside. This is the same with [24]. In the process of transformation, there's re some initiator variables that push person's growth. Along the process, people will found some obstacles, which if it can colved by person who take the shanges, it will be turn to be variables that support the process of transformation.

The result shows that religiousity is the major variable intitating and supporting the process of changes, espescially religious knowledge, practice and experience. This finding is concomitant [25] who describe that both religious experience and religious practice inside the religious conversion bring psychological awareness, integration of love and compassion in one's life, enhanced some personality aspects, like openness and extraversion, capacity to cope with negative feelings and interact with another with compassion and supportive mind, etc.

Inside religiousity, there's praying and $d z i k r$ that helps individuals to start and cope with obstacles. Praying and $d z i k r$ is a kind of religious practice among muslim. One 
method of dzikr is dzikr istighfar that is used within the process of repentance [26]. The repentance process is said to be the first process to enter the process of soul transformation [27], [28]. Repentance is proven to be effective in reducing anxiety and stress [29], and changing sociopathic behavior towards better behaviors and attitudes of life [30].

Repentance is also said to be able to direct individuals to inner peace, negative behavior changes to positive behavior and even individual personality changes [31], [32], [33]. In the process of repentance, guilt and anxiety will arise and this is an important part of the repentance psychotherapy process so that motivation appears to change. This will be followed by removing past bad behavior and character that is done repeatedly.

Repentance also help individual to purifying the spiritual sickness inside the hearts, one variables found to be an obstacle of growth in this research's results. So, with doing repentance, people can initiate and preserve growth from the obstacle which is come in the journey of growth. This long process makes growth be possible through an repentance process.

As an initiating variable, life stressors actually known to generate growth: increased self-awareness, self-acceptance, and social integration [34]. But to promote growth, life stressors need to cognitively reappraised. Here, the role of meaning in life is important to help individuals appraising life stressor to make it promote growth. If there is no cognitive reappraisals, life stressor might be an obstacle of growth, like the finding in this research. This result explain Taubman and Ben-Ari finding about the relation between cognitive assessment of challenges process and growth [35].

In process of giving the meaning, the subjects feeling God's influence in the growth that occurred. Based on FGD process, it is revealed that this happens in the framework that God is perceived by the subject as the One who helps participants overcome the problem of life. This perspective is actually one of the most important parts in the growth of individual spirituality that supports growth in every domains. So, the position of self control seems balance over the effort to generate positive changes and self surrending. This finding reflect form of spirituality that maintaining peace of mind [36] that maintain spiritual connectedness in performing worship [37] which bring personal transformation

The inspiring model also found initiating and supporting the process of transformation. In this research, it refers to one person whose roles as principle and school consultant. Based on the FGD, it was explored that this person regarded by the teachers as a leader who has undergone the growth process. This is an important point in the process of growth of the teachers. As a model, a leader who has undergone the growth process being an example and directing inside the way of changes.

This process besides going through the process of meeting with teachers in routine forums, leaders also always pray for the teachers so that the teachers feel as touched spiritually. This process is supported by the explanation of McCullough and Larson regarding a type of prayer called intercessory prayer, namely prayer for others. In his description, McCullough told about people with heart disease who were guided to pray for each other to make themselves and those who were prayed more able to see their condition and feel an increase in welfare [38].

In the process of intercessory prayer, there is no direct contact or involvement of intercessors and people who are the target of prayer. Simao, Caldera and Carvalho reviewed studies on intercessory prayer and found that in clinical practice, intercessory prayer can have positive effects such as decreased anxiety levels, and depression, success 
and increased implantation and pregnancy; better physical function; decrease in the number of deaths in blood vessel infection patients; reduction in the number of days of care for coronary heart care unit patients, and patients with heart problems [39] .

Social support systems is known to be an influencing factor of mothers' growth [40]. Taubman and Ben-Ari explain that individual growth can be observed by significant others [41]. Significant others can tell their observation of the changes of individual. This process help reinforce the growth [42]. The growth also can be improved by experiencing it together with another people. In this study, other people as a sources of support not only came from the closest family but also from fellow teachers in the school. The form of social support here were specific at emotionally and informationally support. Emotionally social support has the bigger role than another form of social support for both initiating and supporting the process of growth.

In initiating the process of transformation, participant perceive that age naturally lead personal growth. These results appear inconsistent and contrary to the findings of Taubman and Ben-Ari which also explain that age is an important variable in maternal growth [43]. In Taubman and Ben-Ari, young mothers are reported to feel more grown compared to older age. Based on this, the age as a demographic variable needs to be explored in relation to growth in individuals [44].

Another findings in this research is some internal factors found also initiating and supporting transformation process like individual's need for changes, self control, readiness of change, and self efficacy. There are also another obstacles of growth, named as significant others and individual dependency.

Significant others actually knew as the source of psychological distress and make some hindrance inside the relationship [45]. This result might also affected by gender, which in this research, the participants dominantly women. Research found that African American women were likely to report strains related to physical health, interpersonal relations, and gender roles in the family. Dependency as an obstacle can be explained by Cankaya's research which found that autonomy can make individual intentionally driven to explore their new environment for self development and growth [46]. So, lack of autonomy - or can said as dependency - it might be an obstacle for individuals to growth. 
From the process that was carried out thoroughly, it was seen that this research was an initial process which still needed a further process of deepening the findings. It also needs to be clarified about the variables that affect the growth process both initiation and the continuation process so that it can maximize the growth process and minimize the negative effects of changes that occur. Various reviews of the process that occur can be an idea for further research on growth and growth/transformation.

\section{Conclusion And Recommendation}

In the conclusion, religiousity, social support, and meaning of life seems dominantly initiate and support the transformation process. Another variables also found as initiative and supporting variables. In this research, seems that obstacle of transformation come from stressor in life, significant others, also internal factors like spiritual sickness in the heart, and dependency. Further process of deepening the findings is needed. 


\section{References}

[1] Schultz, D. Psikologi pertumbuhan. Sleman: Kanisius. (2017).

[2] Rather, A. R. Psychology of learning and development. New Delhi: Discovery Publishing House. (2007).

[3] Dowson, M. and Miner, M. 'Towards a theory of personal maturity. In Beyond Well Being: spirituality and human flourishing.', in Miner, M., Dowson, M., and Devenish, S. (eds) Beyond Well Being: Spirituality and Human Flourishing. Charlotte: Information Age Publishing, Inc, pp. 127-149. (2012).

[4] Rather, A. R. Psychology of learning and development. New Delhi: Discovery Publishing House. (2007).

[5] Sheldon, K. M. et al. 'Personal goals and psychological growth: testing an intervention to enhance goal attainment and personality integration', Journal of personality, 70(1), pp. 5-31. doi: 10.1111/1467-6494.00176. (2002).

[6] Sheldon, K. M. et al. 'Personal goals and psychological growth: testing an intervention to enhance goal attainment and personality integration', Journal of personality, 70(1), pp. 5-31. doi: 10.1111/1467-6494.00176. (2002).

[7] Sheldon, K. M. et al. 'Personal goals and psychological growth: testing an intervention to enhance goal attainment and personality integration', Journal of personality, 70(1), pp. 5-31. doi: 10.1111/1467-6494.00176. (2002).

[8] Geise, A. C. Personal growth and personality development: well-being and ego development. (Unpublished Master Thesis). University of Missouri. (2008).

[9] Taubman, O. and Ben-Ari. 'Becoming and developing: personal growth in the wake of parenthood and grandparenthood', in The Social Psychology of Meaning, Morality, and Choice. Herzliya, pp. 1-26. (2001).

[10] Taubman, O. and Ben-Ari. 'Becoming and developing: personal growth in the wake ofparenthood and grandparenthood', in The Social Psychology of Meaning, Morality, and Choice. Herzliya, pp. 1-26. (2001).

[11] Skeath, P. et al. 'The nature of life-transforming changes among cancer survivors', Qualitative health research, 23, pp. 1155-67. doi: 10.1177/1049732313499074. (2013).

[12] Owens, J. E. et al 'Stories of growth and wisdom: a mixed-methods study of people living well with pain', Global Advances in Health and Medicine, 5(1), pp. 16- 28. doi: 10.7453/gahmj.2015.065. (2016).

[13] Bauer, J. J. and McAdams, D. P. 'Personal growth in adults'stories of life transitions', Journal of Personality, 72(3), pp. 573-602. (2004).

[14] Sheldon, K. M. et al. 'Personal goals and psychological growth: testing an intervention to enhance goal attainment and personality integration', Journal of personality, 70(1), pp. 5-31. doi: 10.1111/1467-6494.00176. (2002).

[15] Trimulyaningsih, N., Subandi and Yuniarti, K. W. Growth and maturity among teachers in an Islamic character school (Unpublished research report). Yogyakarta. (2018).

[16] Kovel, J. Beyond the future of an illusion: Further reflections on Freud and religion. Psychoanalytic review, 77(1), 69-87 Maslow, A. H. (2012) Toward psychology of being. United States of America: Start Publishing. (1990).

[17] Iqbal, N. et al. 'An interpretative phenomenological analysis of a religious conversion', Journal of Religion and Health. Springer US, 58(2), pp. 426-443. doi: 10.1007/s10943-017-0463-4. (2019).

[18] Taubman, O. and Ben-Ari. 'Becoming and developing: personal growth in the wake of parenthood and grandparenthood', in The Social Psychology of Meaning, Morality, and Choice. Herzliya, pp. 1-26. (2001). 
[19] Taubman, O. and Ben-Ari. 'Becoming and developing: personal growth in the wake of parenthood and grandparenthood', in The Social Psychology of Meaning, Morality, and Choice. Herzliya, pp. 1-26. (2001).

[20] Taubman, O. and Ben-Ari. 'Becoming and developing: personal growth in the wake of parenthood and grandparenthood', in The Social Psychology of Meaning, Morality, and Choice. Herzliya, pp. 1-26. (2001).

[21] Taubman, O. and Ben-Ari. 'Becoming and developing: personal growth in the wake of parenthood and grandparenthood', in The Social Psychology of Meaning, Morality, and Choice. Herzliya, pp. 1-26. (2001).

[22] Rather, A. R. Psychology of learning and development. New Delhi: Discovery Publishing House. (2007).

[23] Rather, A. R. Psychology of learning and development. New Delhi: Discovery Publishing House. (2007).

[24] Iqbal, N. et al. 'An interpretative phenomenological analysis of a religious conversion', Journal of Religion and Health. Springer US, 58(2), pp. 426-443. doi: 10.1007/s10943-017-0463-4. (2019).

[25] Iqbal, N. et al. 'An interpretative phenomenological analysis of a religious conversion', Journal of Religion and Health. Springer US, 58(2), pp. 426-443. doi: 10.1007/s10943-017-0463-4. (2019).

[26] Susanto, D. 'Psikoterapi religius sebagai strategi dakwah dalam menanggulangi tindak sosiopatic (Studi di Pondok Pesantren Istighfar Semarang)', Konseling Religi: Jurnal Bimbingan Konseling Islam, 4(1), pp. 15-32. (2013).

[27] Shafii, M. Psikoanalisis dan sufisme. Edited by Subandi. Yogyakarta: Campus Press. (2004).

[28] Hoddin, M. S. and Thullab, N. 'Konsep taubat tarekat Naqshabandiyah muzhariyah', Teosofi: Jurnal Tasawuf dan Pemikiran Islam, 2(1), pp. 29-48. (2012).

[29] Salam, U. B. et al. 'Potentiality of taubah (Islamic repentance) and listening to the Holy Quran recitation on galvanic skin response', International Journal of Psychology and Counselling, 5(2), pp. 33-37. doi: 10.5897/IJPC12.034. (2013).

[30] Susanto, D. 'Psikoterapi religius sebagai strategi dakwah dalam menanggulangi tindak sosiopatic (Studi di Pondok Pesantren Istighfar Semarang)', Konseling Religi: Jurnal Bimbingan Konseling Islam, 4(1), pp. 15-32. (2013).

[31] Shafii, M. Psikoanalisis dan sufisme. Edited by Subandi. Yogyakarta: Campus Press. (2004).

[32] Hoddin, M. S. and Thullab, N. 'Konsep taubat tarekat Naqshabandiyah muzhariyah', Teosofi: Jurnal Tasawuf dan Pemikiran Islam, 2(1), pp. 29-48. (2012).

[33] Salam, U. B. et al. 'Potentiality of taubah (Islamic repentance) and listening to the Holy Quran recitation on galvanic skin response', International Journal of Psychology and Counselling, 5(2), pp. 33-37. doi: 10.5897/IJPC12.034. (2013).

[34] Sheldon, K. M. et al. 'Personal goals and psychological growth: testing an intervention to enhance goal attainment and personality integration', Journal of personality, 70(1), pp. 5-31. doi: 10.1111/1467-6494.00176. (2002).

[35] Taubman, O. and Ben-Ari. 'Becoming and developing: personal growth in the wake of parenthood and grandparenthood', in The Social Psychology of Meaning, Morality, and Choice. Herzliya, pp. 1-26. (2001).

[36] Memaryan, N., Rassouli, M. and Mehrabi, M. 'Spirituality concept by health professionals in Iran: a qualitative study', Evidence-Based Complementary and Alternative Medicine. Hindawi Publishing Corporation, 2016, pp. 1-9. doi: 10.1155/2016/8913870. (2016).

[37] Nabil, A. et al. “" I can " t pray' - the spiritual needs of Malaysian Muslim patients suffering from depression', International Medical Journal Malaysia, 15(1), pp. 102-109. (2016). 
[38] McCullough, M. E. and Larson, D. B. 'Prayer', in Miller, W. R. (ed.) Integrating Spirituality into Treatment: Resources for Practitioners. Washington, D. C.: American Psychological Association, pp. 85- 110. (1999).

[39] Simao, T. P., Caldera, S. and Carvalho, E. C. de. 'The effect of prayer on patients' health: systematic literature review', Relogions, 7(11), pp. 1-11. doi: 10.3390/rel7010011. (2016).

[40] Taubman, O. and Ben-Ari. 'Becoming and developing: personal growth in the wake of parenthood and grandparenthood', in The Social Psychology of Meaning, Morality, and Choice. Herzliya, pp. 1-26. (2001).

[41] Taubman, O. and Ben-Ari. 'Becoming and developing: personal growth in the wake of parenthood and grandparenthood', in The Social Psychology of Meaning, Morality, and Choice. Herzliya, pp. 1-26. (2001).

[42] Taubman, O. and Ben-Ari. 'Becoming and developing: personal growth in the wake of parenthood and grandparenthood', in The Social Psychology of Meaning, Morality, and Choice. Herzliya, pp. 1-26. (2001).

[43] Taubman, O. and Ben-Ari. 'Becoming and developing: personal growth in the wake of parenthood and grandparenthood', in The Social Psychology of Meaning, Morality, and Choice. Herzliya, pp. 1-26. (2001).

[44] Taubman, O. and Ben-Ari. 'Becoming and developing: personal growth in the wake of parenthood and grandparenthood', in The Social Psychology of Meaning, Morality, and Choice. Herzliya, pp. 1-26. (2001).

[45] Walen, H. R. and Lachman, M. E. 'Social support and strain from partner, family, and friends : Costs and benefits for men and women in adulthood', 17, pp. 5- 30. (2000).

[46] Cankaya, E. M. 'Curiosity and autonomy as factors that promote personal growth in the cross-cultural transition process of international students', Journal of International Students, 8(4), pp. 1694-1708. doi: 10.5281/zenodo.1468072. (2018). 